\title{
THE EFFECTS OF PRUNING AT DIFFERENT TIMES ON THE GROWTH, PHOTOSYNTHESIS AND YIELD OF GONILON GOFFEE (COFFEA CANEPHORA) GLONES WITH VARYING PATTERNS OF FRUIT MATURATION IN SOUTHEASTERN BRAZIL
}

\author{
By L. E. MORAIS $\dagger$, P. C. CAVATTE $\dagger$, E. F. MEDINA $\dagger$, P. E. M. SILVA $\dagger$, \\ S. G. V. MARTINS $\dagger$, P. S. VOLPI $\S$, S. ANDRADE JÚNIOR \\ J. A. MACHADO FILHO, G. P. RONGHI $\dagger \dagger$ and F. M. DAMATTA $\dagger$, \\ $\dagger$ Departamento de Biologia Vegetal, Universidade Federal de Viçosa, 36570-000 Viçosa, MG, \\ Brasil, §Instituto de Pesquisa, Assistência Técnica e Extensão Rural do Espirito Santo, \\ 29725-000 Marilândia, ES, Brasil, 『Instituto de Pesquisa, Assistência Técnica e Extensão \\ Rural do Espirito Santo, 29915-140 Linhares, ES, Brasil and ††Campus Rio Paranaíba, \\ Universidade Federal de Viçosa, 38810-000 Rio Paranaíba-MG, Brasil
}

(Accepted 21 September 2011; First published online 19 October 2011)

SUMMARY

\begin{abstract}
The economics of coffee plantations is intrinsically linked to pruning, which can improve the canopy architecture and thereby increase productivity. However, recommended pruning times on conilon coffee plantations have been made on an entirely empirical basis. In this study, by evaluating growth, photosynthetic gas exchanges, starch accumulation and crop productivity, the effects of pruning at different times between harvest and flowering were investigated for six conilon coffee clones with distinct stages of fruit maturation (early, intermediate and late). Clones with an early maturation stage were pruned at four different times: 0, 30, 60 and 90 days after harvest (DAH). Intermediate clones were pruned at 0, 30 and $60 \mathrm{DAH}$, and late clones were pruned at 0 and $30 \mathrm{DAH}$. Overall, the rates of shoot growth and net photosynthesis, the stomatal conductance and the crop yield were not affected by the pruning treatments in any of the clones. In addition, pruning times did not affect the concentrations of starch or the photochemical efficiency of photosystem II. The carbon isotope composition ratio was marginally affected by the treatments. These results suggest that the pruning time after harvests is relatively unimportant and pruning operations can be scheduled to optimise the use of labour, which directly impacts the production costs of coffee.
\end{abstract}

\section{INTRODUCTION}

After oil products, coffee is the second most commonly traded commodity worldwide. On a broader scale, when all steps from cultivation to the sale of final consumable products are considered, the international coffee trade involves approximately 500 million people (DaMatta et al., 2010). Of the approximately 100 species of the genus Coffea (Davis et al., 2006), only C. arabica L. (arabica coffee) and C. canephora Pierre ex A. Froehner (robusta coffee) are economically important worldwide; these two species are responsible for $99 \%$ of world bean production. Currently, arabica 
coffee accounts for approximately $62 \%$ of the consumed coffee, and robusta coffee accounts for the rest. Robusta is the most widely cropped cultivar of $C$. canephora in the world, and the name of this cultivar designates the common name of the species. In Brazil, kouillou (also known as conilon) is practically the sole cropped cultivar of $C$. canephora (DaMatta and Ramalho, 2006).

Coffea canephora displays a multi-stem architecture. It has multiple vertical, or orthotropic, branches from which the productive (horizontal) plagiotropic branches emerge. Until recently, conilon plants on Brazilian coffee plantations were allowed to grow freely. This leads to a high degree of self-shading and a consequent reduction in the penetration of sunlight into the canopy. Moreover, the free growth of conilon coffee accelerates the aging of plantations because the leaf area associated with photosynthesis decreases as the total dry mass of the plant increases. This is a result of an excess of orthotropic branches, which increase the demand for photoassimilates. The small leaf area cannot adequately supply this demand, so the vitality and, consequently, the productivity of the crop decline (Ronchi and DaMatta, 2007). Thus, the economical operation of coffee plantations is intrinsically linked with the efficiency of the pruning system, which can improve yields and ensure the longevity of the plantation.

The formation of new shoots after pruning produces changes in the plant, especially in the stores of carbohydrate and nitrogen. The quantity of nutrients stored and the plant's ability to govern their translocation largely determine the success with which new branches are formed (Berninger et al., 2000; Ourry et al., 1994). The partial removal of foliage can improve the net carbon assimilation rate $(A)$ in the remaining foliage due to changes in the source/sink relationship (DaMatta et al., 2008) and increase the amount of light that penetrates into the canopy. This can partially offset the reduction in photosynthesis on a whole plant basis associated with a decreased leaf area after pruning.

The period between harvest and flowering in Brazil (usually in mid-September) can last for more than three months, as observed in early maturing conilon coffee clones. Based on empirical observations, pruning during this period has been recommended (Ferrão et al., 2004; Silveira and Rocha, 1995). Recently, Fonseca et al. (2007) suggested that pruning immediately after harvest could be advantageous because it would allow faster recovery from the damage and stress caused by harvesting and pruning activities. However, at the farm level, pruning is commonly performed in July and August for both early and intermediate maturing crops, which are harvested in April and May, and late maturing crops, which are harvested just before pruning. Thus, pruning occurs when the entire harvest is finished, weeks or even days before flowering begins.

No scientific studies have documented the effects of pruning at different times on the physiology and yield of coffee trees. This lack of understanding obstructs the issuance of recommendations on pruning times for clones with different fruit maturation periods and has confounded answers to the following questions. When, during the period between harvest and flowering, can the coffee tree be pruned without interfering with its growth and production? What are the effects of pruning at different times on the growth, carbon economy and production capacity of clones with different patterns of fruit maturation? 


\section{Cultivation conditions and treatments}

Experiments were conducted at the experimental farm of the Institute for Research and Rural Assistance of Espírito Santo State (INCAPER) in Marilândia (19 $407^{\prime}$ S, $40^{\circ} 539^{\prime} \mathrm{W}, 110 \mathrm{~m}$ a.s.l.), northwestern region of Espírito Santo, Brazil. The soil at the location is classified as a strongly undulated, dystrophic red Latosol. The site receives an average annual rainfall of $1200 \mathrm{~mm}$, with a marked dry season from March or April to September or October. The average annual temperature is $24.0^{\circ} \mathrm{C}$. Experiments were conducted on a mature conilon coffee crop planted in rows with a spacing of 2.5 $\times 1.0 \mathrm{~m}$. Each row consisted of a single clone and was oriented from north to south. There were 16,000 productive stems (orthotropic heads) per hectare and shoots of different ages. The crop was grown without irrigation, and the recommended cultural practices (e.g. weeding, fertilising and pest control) for conilon coffee plantations were applied.

Beginning in May 2006, farm renewal was initiated using the renewal pruning methods described by Ronchi (2009). Approximately 50\% of older orthotropic branches, plagiotropic branches in the lower part of the canopy that had no production potential and all existing shoots were removed; only 8000 productive orthotropic stems per hectare (two stems per plant) remained. Three thinnings were performed in October and December 2006 and February 2007, leaving, in addition to two productive stems, three buds per plant to renew the crop the following year. The early, intermediate and late clones were harvested in May, June and July 2007, respectively. In addition, after harvesting in 2007, old stems were removed at the precise pruning times specified for the treatments for each group of clones (see below). In August 2007, the crop was completely renewed, with 12,000 one-year-old stems per hectare. In subsequent years, while following the pruning and harvesting regimens for each clone, production pruning was conducted to remove all shoots and the plagiotropic branches that had reached $70 \%$ of their production capacity (Fonseca et al., 2007). Therefore, 12,000 productive stems per hectare were preserved during the evaluated crop seasons (i.e. 2008, 2009 and 2010).

In total, 18 treatments arranged in incomplete blocks were tested, with four replicates of each treatment. Each experimental plot consisted of rows of coffee trees with 10 plants, and the eight central plants were used in the experiments. Six conilon coffee clones with distinct stages of fruit maturation (03 and 67, early; 16 and 120, intermediate; and 19 and 76, late maturation stages) were evaluated. The entire fruit development (from bloom to full ripening) period lasts, on average, for 34, 41 and 45 weeks for early, intermediate and late clones, respectively (Ronchi and DaMatta, 2007). Depending on the maturation times of the clones, the treatments consisted of different pruning times after harvest. The early maturation clones had less time for fruit formation and were harvested on May 15. Because this harvest time was the furthest from the time of flowering, which usually occurs in September, these clones were pruned at four different times, i.e. 0 (May 15), 30 (June 15), 60 (July 15) and 90 (August 15) DAH. For the intermediate maturation clones, the harvest was performed 
on June 15 and three pruning treatments were applied: 0 (June 15), 30 (July 15) and 60 (August 15) DAH. In the late clones, the fruits required more time to reach maturity; the crop was harvested on July 15, and because the bloom occurs soon after harvest, only two prunings were performed: 0 (July 15) and 30 (August 15) DAH.

\section{Growth and productivity}

Plant growth in the upper third of the plant canopy was evaluated. From June 2008 to April 2010, the length of each branch (six primary plagiotropic branches per replicate) was measured with a tape measure. The absolute growth rate (AGR) of branches was also estimated. In January 2010, plagiotropic branches located in the middle third of the plant were collected from six plants per treatment (three branches per plant). The leaf area was determined from these branches by measuring the maximum width and length of each leaf and using the equations described by Antunes et al. (2008). The fruits and leaves were then dried at $70{ }^{\circ} \mathrm{C}$ and weighed. With this information, the ratios between the dry mass of leaves and the fruit dry mass (LMFR) and between the leaf area and the fruit dry mass (LAFR) were calculated.

In 2008, 2009 and 2010, fruit from the early, intermediate and late clones were harvested in May, June and July, respectively. Harvests were performed when more than $50 \%$ of fruits were ripe (red colour). The fruits were dried and weighed according to the standard procedures for coffee. The yield data, expressed in kilograms of processed coffee per hectare, refer to the average of three harvests.

\section{Physiological evaluations}

Physiological evaluations were performed at two distinct phenological times: before flowering (27-29 August 2009) and post-anthesis, in the 'pinhead' fruit phase (25-28 September 2009). For six plants from each treatment, three leaves from the east side and three from the west side of the orchard rows were assessed. All measurements and leaf samples were taken from the third or fourth leaf pair from the apex of the plagiotropic branches in the middle third of the plants. The stomatal conductance $\left(g_{\mathrm{s}}\right)$ and net carbon assimilation rate $(A)$ were assessed with a portable infrared LI-6400 gas analyser (LI-COR Biosciences Inc., NE, USA) equipped with a blue/red light source, model LI-02B-6400 (LI-COR). Measurements were performed in the morning under ambient $\mathrm{CO}_{2}$, temperature and humidity conditions with a photosynthetic photon flux density of $1000 \mu \mathrm{mol} \mathrm{m} \mathrm{m}^{-2}$.

The leaf carbon isotope composition ratio $\left(\delta^{13} \mathrm{C}\right)$, which provides an integrated measurement of internal plant physiological and external environmental properties influencing photosynthetic gas exchange over time (Farquhar et al., 1989), was measured relative to the international Pee Dee Belemnite (PDB) standard with a mass spectrometer (Delta-S Finnigan MAT, Bremen, Germany) as described previously (DaMatta et al., 2002).

Chlorophyll a fluorescence parameters were measured immediately after gasexchange measurements with a portable pulse amplitude modulation fluorometer (MINI-PAM, Walz, Effeltrich, Germany). The quantum yield of photosystem II 
(PSII) electron transport $\left(\Phi_{\text {PSII }}\right)$ and the apparent electron transport rate $(\mathrm{ETR})$ under ambient light conditions were estimated as described previously (Chaves et al., 2008; DaMatta et al., 2002). In addition, the minimum $\left(\mathrm{F}_{0}\right)$ and maximum $\left(\mathrm{F}_{\mathrm{m}}\right)$ dark-adapted (30 min) fluorescence values were measured using a dark-adaptation leaf clip. From these values, the $F_{\mathrm{v}} / \mathrm{F}_{\mathrm{m}}$ ratio, where $\mathrm{F}_{\mathrm{v}}=\mathrm{F}_{\mathrm{m}}-\mathrm{F}_{0}$, was calculated. This ratio has been used as a measure of the potential photochemical efficiency of PSII.

In order to quantify the amount of starch in leaves, leaf tissues were collected around midday and frozen immediately in liquid nitrogen. The samples were lyophilized at $-48^{\circ} \mathrm{C}$ and crushed in a cell disruptor with 3.2-mm metal beads (Mini-BeadBeater96, BioSpec Products, Bartlesville, OK, USA). A 10-mg sample of ground tissue was added to pure methanol, and the mixture was incubated at $70{ }^{\circ} \mathrm{C}$ for $30 \mathrm{~min}$. After centrifugation $(13,000 \mathrm{~g}, 5 \mathrm{~min})$, the supernatant was discarded, and the starch in the pellet was quantified according to Praxedes et al. (2006).

\section{Statistical analysis}

The experimental design included incomplete blocks in a split plot design. In the primary plot, six clones $(03,16,19,67,76$ and 120) with different times of fruit maturation (two clones per fruit maturation time) were distributed, and within each clone group, different pruning times $(0,30,60$ and $90 \mathrm{DAH}$, depending on the clone) were applied to form subplots. The data were subjected to an analysis of variance, and the averages were compared using the Newman-Keuls test at a $5 \%$ probability with the program Statistical and Genetic Analysis, UFV 5.0 (Sistemas de Análises Estatísticas e Genéticas (SAEG), 1993). The results are expressed as averages \pm standard error (SE).

\section{RESULTS}

There was no significant difference in the AGR among treatments during the experiment, except for clone 120. For this particular clone, the plants pruned immediately after harvest had the AGR $\left(1.24 \mathrm{~mm} \mathrm{~d}^{-1}\right)$ that was approximately $25 \%$ and 20\% higher than the plants pruned 30 and 60 DAH, respectively (Figure 1). No significant difference was observed in the LMFR and LAFR values among treatments (Figure 1). Yields, which ranged from $2082 \mathrm{~kg} \mathrm{ha}^{-1}$ (clone 19) to $3984 \mathrm{~kg} \mathrm{ha}^{-1}$ (clone 76), were not significantly affected by the pruning treatments (Figure 1).

In August 2009, the average values of $g_{\mathrm{s}}$ differed only in clone 76 and were $54 \%$ higher in plants pruned immediately after harvest compared with those pruned 30 DAH (Figure 2). In September, the pruning time did not affect $g_{\mathrm{s}}$ (Figure 3) in any of the clones. The $A$ value was similar for all pruning times and clones in August and September (Figures 2 and 3). In August, significant variations in $\delta^{13} \mathrm{C}$ were observed in clones 67 and 120; however, they were inconsistent among treatments (Figure 2). In September, $\delta^{13} \mathrm{C}$ was not affected by the pruning treatment (Figure 3 ).

In August, the maximum photochemical efficiency of PSII $\left(\mathrm{F}_{\mathrm{v}} / \mathrm{F}_{\mathrm{m}}\right)$ was similar in all treatments. For each clone, ETR did not vary consistently in response to pruning times, with the exception that ETR was generally lower in clones pruned at 0 DAH 

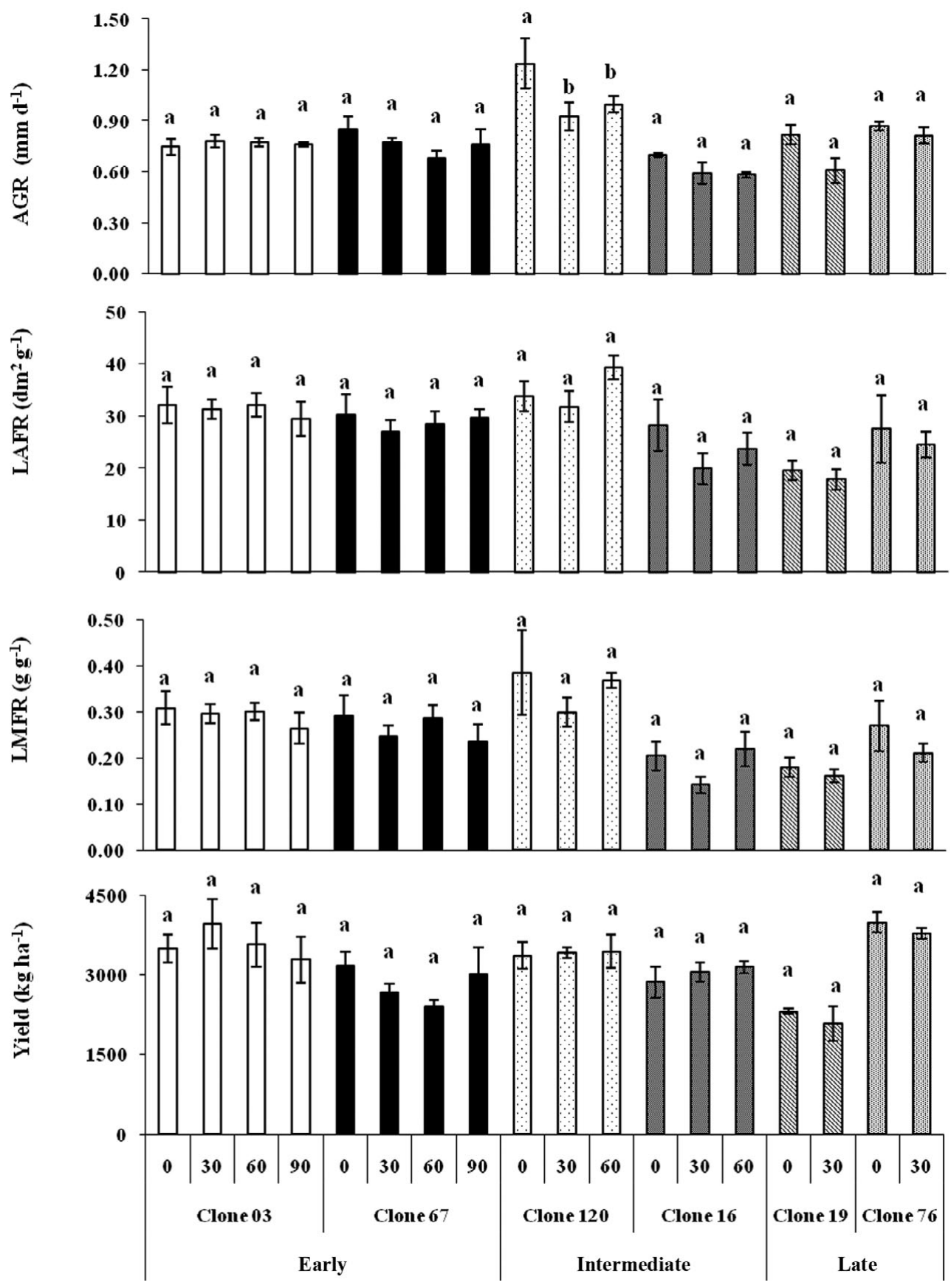

Figure 1. Effect of different pruning times (0, 30, 60 and 90 days after harvest (DAH)) in conilon coffee clones $(03,67$, $120,16,19$ and 76) on the absolute growth rate (AGR) of branches, the leaf area to fruit mass ratio (LAFR), the leaf mass to fruit mass ratio (LMFR) and crop yield. Values followed by the same letter do not significantly differ within each clone (the Newman-Keuls test, $P>0.05$ ). 

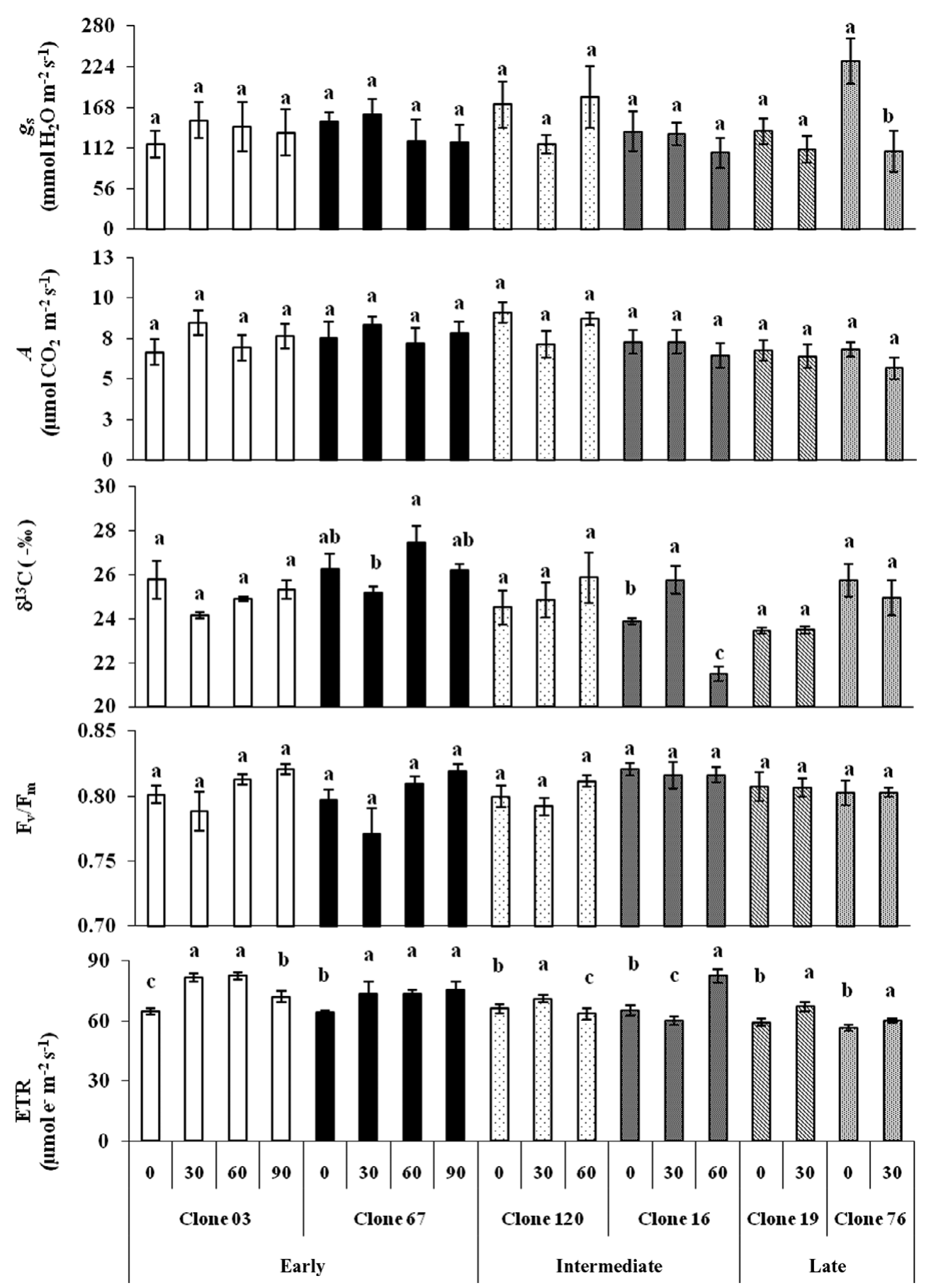

Figure 2. Effect of different pruning times $(0,30,60$ and $90 \mathrm{DAH})$ in conilon coffee clones $(03,67,120,16,19$ and 76$)$ on the stomatal conductance $\left(g_{\mathrm{s}}\right)$, net carbon assimilation rate $(A)$, carbon isotope composition ratio $\left(\delta^{13} \mathrm{C}\right)$, maximum photochemical efficiency of PSII $\left(\mathrm{F}_{\mathrm{v}} / \mathrm{F}_{\mathrm{m}}\right)$ and electron transport rate $(\mathrm{ETR})$ in August 2009. Values followed by the same letter do not significantly differ within each clone (the Newman-Keuls test, $P>0.05$ ). 

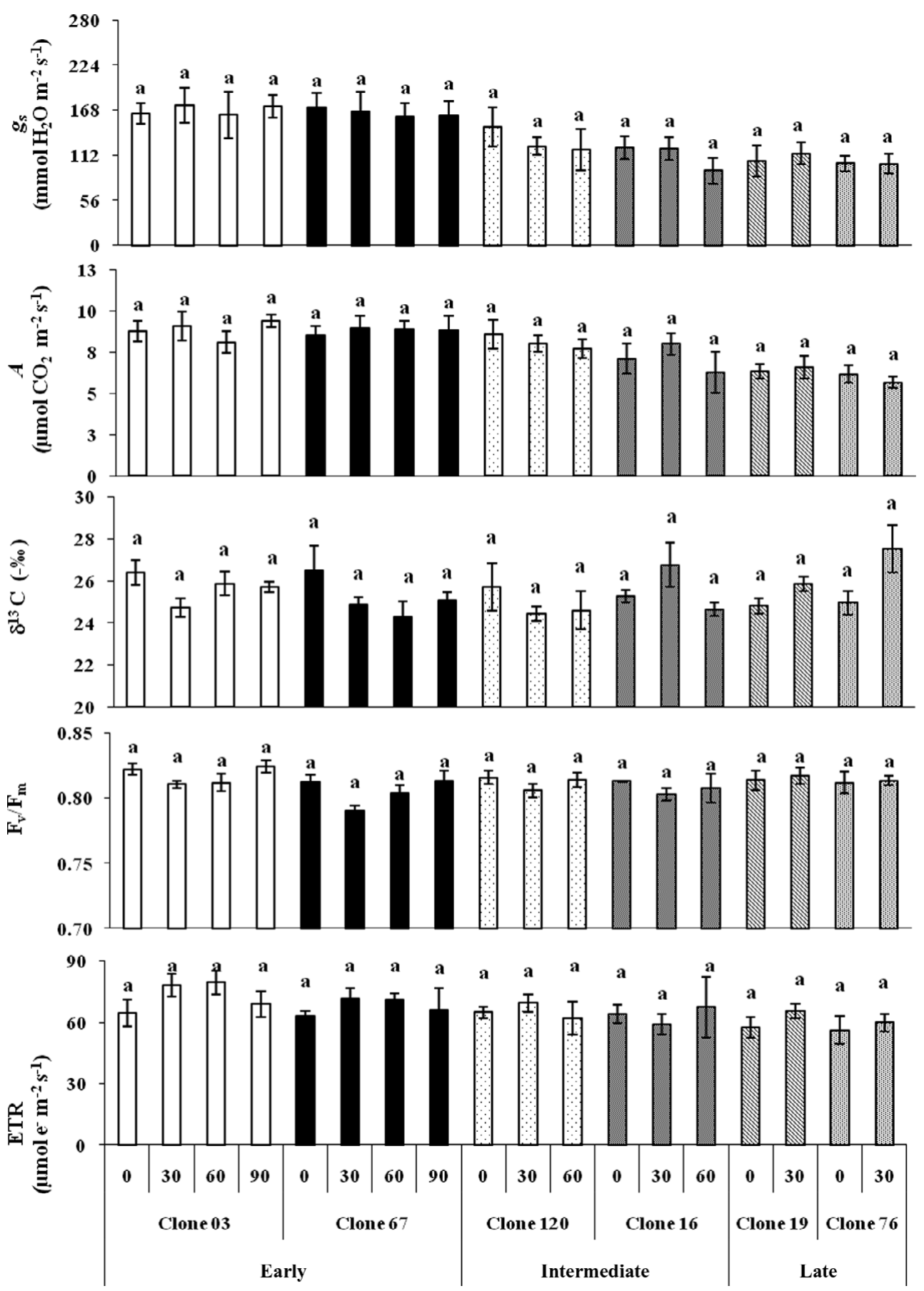

Figure 3. Effect of different pruning times (0, 30, 60 and $90 \mathrm{DAH})$ in conilon coffee clones $(03,67,120,16,19$ and 76$)$ on the stomatal conductance $\left(g_{\mathrm{s}}\right)$, net carbon assimilation rate $(A)$, carbon isotope composition ratio $\left(\delta^{13} \mathrm{C}\right)$, maximum photochemical efficiency of PSII $\left(\mathrm{F}_{\mathrm{v}} / \mathrm{F}_{\mathrm{m}}\right)$ and electron transport rate $(\mathrm{ETR})$ in September 2009. Values followed by the same letter do not significantly differ within each clone (the Newman-Keuls test, $P>0.05$ ). 

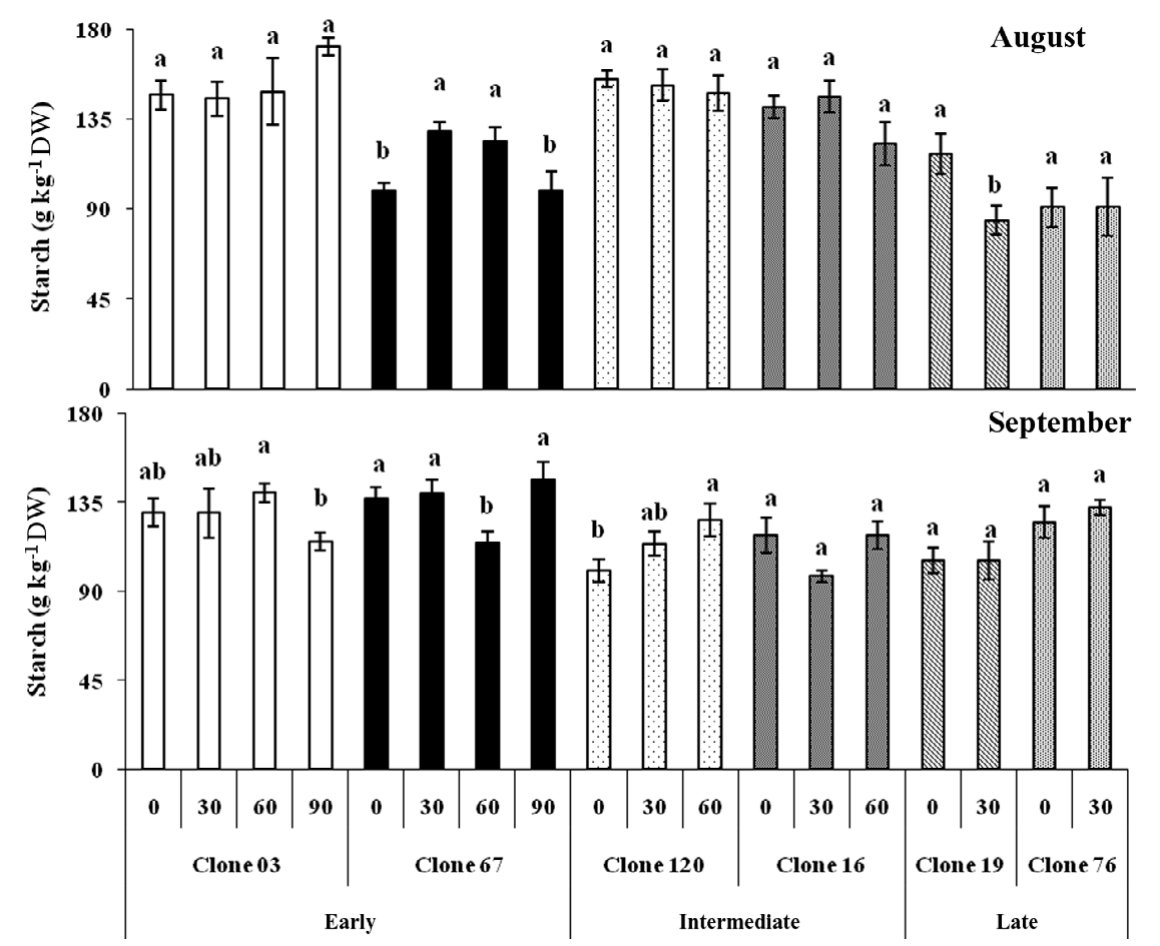

Figure 4. Effect of different pruning times (0, 30, 60 and $90 \mathrm{DAH})$ in conilon coffee clones $(03,67,120,16,19$ and 76) on the foliar starch concentration in August and September 2009. Values followed by the same letter do not significantly differ within each clone (the Newman-Keuls test, $P>0.05)$.

compared with later prunings (Figure 2). In September, no significant variations in the fluorescence parameters were observed, irrespective of the pruning time, within each clone group (Figure 3).

In August, in clone 67, lower starch concentrations were recorded in the leaves of plants pruned at 0 and $90 \mathrm{DAH}$, while in clone 19, the starch concentration was significantly lower $(28 \%)$ in plants pruned at $30 \mathrm{DAH}$ compared with plants pruned immediately after harvest. In other clones, no significant changes in the concentrations of starch as a function of pruning time were observed (Figure 4). The highest absolute concentrations of starch were observed in clone 03 (171 g starch $\mathrm{kg}^{-1}$ dry weight (DW)). In September, there were no consistent changes in starch concentrations in response to different pruning times (Figure 4). The early clones had higher concentrations, reaching $146 \mathrm{~g}$ starch kg-1 DW in clone 67 at $90 \mathrm{DAH}$. The lowest absolute concentration of starch $\left(98 \mathrm{~g}\right.$ starch $\left.\mathrm{kg}^{-1} \mathrm{DW}\right)$ was observed in clone 16 at $30 \mathrm{DAH}$.

\section{DISCUSSION}

Overall, the growth rates of the plagiotropic branches were not affected by the pruning treatments. Although the number of nodes was not quantified, the average 
length between nodes was not significantly affected by the pruning treatments (data not shown). This suggests that the number of nodes was also not affected, and therefore, the number of potentially productive nodes should not be affected during the following growing season. Indeed, the yield of the clones was not affected by the pruning treatments. Therefore, from a scientific point of view, pruning can be performed immediately after harvest, as proposed by Fonseca et al. (2007), or later, before flowering, without affecting yields. These results suggest that pruning operations between the harvest and subsequent flowering can be staggered without adversely affecting the physiology of the coffee tree or the plant production. This would help to optimise the use of labour and, thus, result in lower production costs.

The pruning treatments did not affect the magnitude of gas exchange $\left(g_{\mathrm{s}}\right.$ and $A$ ). Moreover, $\delta^{13} \mathrm{C}$, which expresses the magnitude of gas exchange over time instead of a discrete measurement (Farquhar et al., 1989), showed little to no response to the treatments. These results suggest that there was no long-term variation in the photosynthetic rate or the efficiency of water use within each clone in response to pruning at different times. The photosynthetic rates were similar to average values $\left(8.3 \mu \mathrm{mol} \mathrm{CO}_{2} \mathrm{~m}^{-2} \mathrm{~s}^{-1}\right)$ observed in C. canephora plants under appropriate cultivation conditions, as reported by DaMatta et al. (2010). In some cases, the ETR exceeded $80 \mu \mathrm{mol} \mathrm{m} \mathrm{m}^{-2} \mathrm{~s}^{-1}$, a value that is higher than the photochemical needs required to support the observed rates of photosynthesis. A high ETR with a relatively low $A$ usually leads to excess reducing power, which can be used for the production of reactive oxygen species that can trigger a range of photoinhibitory and photooxidative effects (Lima et al., 2002). However, the maximum photochemical efficiency of PSII, estimated by the $\mathrm{F}_{\mathrm{v}} / \mathrm{F}_{\mathrm{m}}$ ratio, did not vary in the treatments, indicating that the plants did not suffer photoinhibitory damage.

Starch concentrations were little affected in the treatments probably because the sink demand was low when leaf samplings were performed (Cannell, 1970; Wormer and Ebagole 1965). Although only leaf concentrations were evaluated, the starch concentration in the leaves was considered to vary in parallel with that in the branches, a phenomenon that has been documented in arabica coffee (e.g., Chaves, 2009; Patel, 1970). The starch content was estimated at the end of the slow growth phase (August) and at the beginning of the growth recovery phase (September). In all cases, the observed starch content was well above the maximum content observed in arabica coffee (approximately $100 \mathrm{~g}_{\text {starch kg}}{ }^{-1}$ DW; Amaral, 1991) during the slow growth phase. The highest starch concentrations should reflect the maintenance of photosynthesis at relatively high rates, even during slow vegetative growth, as shown by DaMatta et al. (2003) and also confirmed in this study. For example, the maximum values of $A$ reported by Silva et al. (2004) under field conditions were approximately $3 \mu \mathrm{mol} \mathrm{CO}_{2} \mathrm{~m}^{-2} \mathrm{~s}^{-1}$ during the slow growth phase of arabica coffee in Viçosa, southeastern Brazil. Therefore, a steady $A$ value in the slow growth phase should allow for greater accumulation of starch in conilon coffee. This could partially explain the greater potential yield of this species compared with arabica coffee (DaMatta et al., 2010). 


\section{GONCLUSION}

Pruning at different times after harvest, irrespective of the fruit maturation time, has little or no influence on the rate of branch growth, photosynthesis, starch content or yield of conilon coffee. The data suggest that, even in the early maturation clones, there is neither an advantage nor a disadvantage to pruning immediately after harvest or later, before flowering. Therefore, because crop productivity is not compromised, pruning operations between harvest and flowering can be scaled up to optimise the use of labour, which directly impacts the production costs of conilon coffee.

Acknowledgements. This research was supported by the Brazilian Consortium for Coffee Research and Development. Scholarships granted by CAPES and CNPq from the Brazilian Government are gratefully acknowledged.

\section{REFERENGES}

Amaral, J. A. T. (1991). Crescimento vegetativo estacional do cafeeiro e suas interações com fontes de nitrogênio, fotoperiodo, fotossíntese e assimilação do nitrogênio. PhD Thesis, Universidade Federal de Viçosa, Brazil.

Antunes, W. C., Pompelli, M. F., Carretero, D. M. and DaMatta, F. M. (2008). Allometric models for non-destructive leaf area estimation in coffee (Coffea arabica and C. canephora). Annals of Applied Biology 153:33-40.

Berninger, F., Nikinmaa, E., Sievanen, R. and Nygren, P. (2000). Modelling of reserve carbohydrate dynamics, regrowth and nodulation in a $\mathrm{N}_{2}$-fixing tree managed by periodic prunings. Plant, Cell E Environment 23;1025-1040.

Cannell, M. G. R. (1970). The contribution of carbohydrates from vegetative laterals to the growth of fruits on the bearing branches of Coffea arabica. Turrialba 20:15-19.

Chaves, A. R. M. (2009). Aspectos fisiológicos do crescimento e da produção do cafeeiro. PhD Thesis, Universidade Federal de Viçosa, Brazil.

Chaves, A. R. M., Ten-Caten, A., Pinheiro, H. A., Ribeiro, A. and DaMatta, F. M. (2008). Seasonal changes in photoprotective mechanisms of leaves from shaded and unshaded field-grown coffee (Coffea arabica L.) trees. Trees 22:351-361.

DaMatta, F. M., Chaves, A. R. M., Pinheiro, H. A., Ducatti, C. and Loureiro, M. E. (2003). Drought tolerance of two field-grown clones of Coffea canephora. Plant Science 164:111-117.

DaMatta, F. M., Gunha, R. L., Antunes, W. G., Martins, S. V. G., Araújo, W. L., Fernie, A. R. and Moraes, G. A. B. K. (2008). In field-grown coffee trees source-sink manipulation alters photosynthetic rates, independently of carbon metabolism, via alterations in stomatal function. New Phytologist 178:348-357.

DaMatta, F. M., Loos, R. A., Silva, E. A. and Loureiro, M. E. (2002). Leaf photosynthetic characteristics of Coffea canephora as affected by nitrogen and water availability. Fournal of Plant Physiology 159:975-981.

DaMatta, F. M. and Ramalho, J. D. C. (2006). Impacts of drought and temperature stress on coffee physiology and production: a review. Brazilian fournal of Plant Physiology 18:55-81.

DaMatta, F. M., Ronchi, C. P., Maestri, M. and Barros, R. S. (2010). Coffee: environment and crop physiology. In Ecophysiology of Tropical Tree Crops, 181-216 (Ed F. M. DaMatta). New York: Nova Science.

Davis, A. P., Govaerts, R., Bridson, D. M. and Stoffelen, P. (2006). An annotated taxonomic conspectus of the genus Coffea (Rubiaceae). Botanical Fournal of the Linnean Society 152:465-512.

Farquhar, G. D., Ehleringer, J. R. and Hubik, K. T. (1989). Carbon isotope discrimination and photosynthesis. Annual Review of Plant Physiology and Plant Molecular Biology 40:503-537.

Ferrão, R. G., Fonseca, A. F. A., Ferrão, M. A. G., De Muner, L. H., Verdin Filho, A. C., Volpi, P. S., Marques, E. M. G. and Zucateli, F. (2004). Técnicas de Produção com Variedades Melhoradas. Vitória, Brazil: Incaper.

Fonseca, A. F. A., Ferrão, R. G., Lani, J. A., Ferrão, M. A. G. and Volpi, P. S. (2007). Manejo da cultura do café conilon: espaçamento, densidade de plantio e podas. In Café Conilon, 257-277. (Eds R. G. Ferrão, A. F. A. Fonseca, S. M. Bragança, M. A. G. Ferrão and L. H. De Muner). Vitória, Brazil: Incaper.

Lima, A. L., DaMatta, F. M., Pinheiro, H. A., Totola, M. R. and Loureiro, M. E. (2002). Photochemical responses and oxidative stress in two clones of Coffea canephora under water deficit conditions. Environmental and Experimental Botany 47:239-247. 
Ourry, A., Kim, T. H. and Boucaud, J. (1994). Nitrogen reserve mobilization during regrowth of Medicago sativa: relationships between availability and regrowth yield. Plant Physiology 105:831-837.

Patel, R. Z. (1970). A note on the seasonal variations in starch content of different parts of Arabica coffee trees. East African of Agricultural and Forest fournal 36:1-4.

Praxedes, S. G., DaMatta, F. M., Loureiro, M. E., Ferrão, M. A. G. and Cordeiro, A. T. (2006). Effects of long-term soil drought on photosynthesis and carbohydrate metabolism in mature robusta coffee (Coffea canephora Pierre var. kouillou) leaves. Environmental and Experimental Botany 56:263-273.

Ronchi, C. P. (2009, June). Emprego adequado da poda para renovação do cafeeiro Conilon. In Anais do VI Simpósio de Pesquisa dos Cafés do Brasil. Vitória, Brasil: Incaper (on CD-ROM).

Ronchi, C. P. and DaMatta, F. M. (2007). Aspectos fisiológicos do café conilon. In Café Conilon, 95-119 (Eds R. G. Ferrão, A. F. A. Fonseca, S. M. Bragança, M. A. G. Ferrão and L. H. De Muner). Vitória, Brazil: Incaper.

Silva, E. A., DaMatta, F. M., Ducatti, C., Regazzi, A. J. and Barros, R. S. (2004). Seasonal changes in vegetative growth and photosynthesis of Arabica coffee trees. Field Crops Research 89:349-357.

Silveira, J. S. M. and Rocha, A. C. (1995). Poda. In Manual Técnico para a Cultura do Café no Estado do Espírito Santo, 54 62. (Eds E. B. Costa, A. E. S. Silva, A. P. M. Andrade Neto and F. A. Daher). Vitória, Brazil: SEAG.

Sistemas de Análises Estatísticas e Genéticas (SAEG) (1993). UFV 5.0. Viçosa: Fundação Arthur Bernardes.

Wormer, T. M. and Ebagole, H. E. (1965). Visual scoring of starch in Coffea arabica L. II. Starch in bearing and non-bearing branches. Experimental Agriculture 1:41-53. 